\title{
Reversible Protonated Resting State of the Nitrogenase Active Site
}

\author{
Christine N. Morrison, ${ }^{\dagger}$ Thomas Spatzal, ${ }^{\dagger,+}$ and Douglas C. Rees ${ }^{*, \dagger, \ddagger(i)}$ \\ ${ }^{\dagger}$ Division of Chemistry and Chemical Engineering and ${ }^{\ddagger}$ Howard Hughes Medical Institute, California Institute of Technology, \\ Pasadena, California 91125, United States
}

Supporting Information

ABSTRACT: Protonated states of the nitrogenase active site are mechanistically significant since substrate reduction is invariably accompanied by proton uptake. We report the low $\mathrm{pH}$ characterization by X-ray crystallography and EPR spectroscopy of the nitrogenase molybdenum iron (MoFe) proteins from two phylogenetically distinct nitrogenases (Azotobacter vinelandii, Av, and Clostridium pasteurianum, $\mathrm{Cp}$ ) at $\mathrm{pHs}$ between 4.5 and 8. X-ray data at $\mathrm{pHs}$ of 4.5-6 reveal the repositioning of side chains along one side of the FeMo-cofactor, and the corresponding EPR data shows a new $S=3 / 2$ spin system with spectral features similar to a state previously observed during catalytic turnover. The structural changes suggest that FeMo-cofactor belt sulfurs S3A or S5A are potential protonation sites. Notably, the observed structural and electronic low $\mathrm{pH}$ changes are correlated and
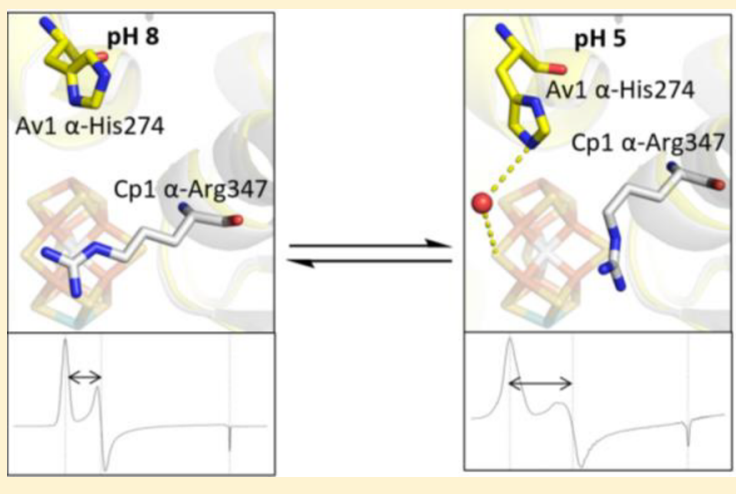
reversible. The detailed structural rearrangements differ between the two MoFe proteins, which may reflect differences in potential protonation sites at the active site among nitrogenase species. These observations emphasize the benefits of investigating multiple nitrogenase species. Our experimental data suggest that reversible protonation of the resting state is likely occurring, and we term this state " $\mathrm{E}_{0} \mathrm{H}^{+”}$, following the Lowe-Thorneley naming scheme.

\section{INTRODUCTION}

Nitrogen fixation is the process of breaking the kinetically inert $\mathrm{N}-\mathrm{N}$ triple bond via either reduction or oxidation of dinitrogen. Biologically, nitrogen fixation is accomplished by the enzyme nitrogenase to yield ammonia, with an overall reaction stoichiometry conventionally described by eq 1 :

$$
\begin{aligned}
& \mathrm{N}_{2}+10 \mathrm{H}^{+}+8 \mathrm{e}^{-}+16 \mathrm{ATP} \\
& \rightarrow 2 \mathrm{NH}_{4}^{+}+\mathrm{H}_{2}+16 \mathrm{ADP}+16 \mathrm{P}_{\mathrm{i}}
\end{aligned}
$$

Nitrogenase is a highly oxygen-sensitive enzyme present in specialized microorganisms; it consists of two proteins called the molybdenum-iron (MoFe) and iron ( $\mathrm{Fe}$ ) proteins. ${ }^{1-3}$ The Fe protein contains two nucleotide binding sites and a $4 \mathrm{Fe}: 4 \mathrm{~S}$ cluster. The MoFe protein incorporates two 8Fe:7S "P-clusters" and two 7Fe:9S:C:Mo:R-homocitrate "FeMo-cofactors", the latter of which represents the active site where substrates bind and are reduced. ATP-dependent electron transfer occurs from the $4 \mathrm{Fe}: 4 \mathrm{~S}$ cluster to the P-cluster during docking interactions between the $\mathrm{Fe}$ and $\mathrm{MoFe}$ proteins, after which the proteins separate. $^{4-6}$ Substrates can only bind to forms of the FeMocofactor more reduced than the resting state. These states are conventionally designated as $\mathrm{E}_{n}$, where $n$ represents the number of electrons transferred to the MoFe protein (per active site), and $\mathrm{E}_{0}$ is the resting state. ${ }^{5}$ Following the Lowe-Thorneley model, dinitrogen binds to the FeMo-cofactor in the $\mathrm{E}_{3}$ and $\mathrm{E}_{4}$ states; however, other substrates, such as acetylene, may bind to the FeMo-cofactor in less highly reduced states. ${ }^{5}$
Electron paramagnetic resonance (EPR) is a powerful tool for studying the electronic states of the FeMo-cofactor since the $\mathrm{E}_{0}$ state exhibits a strong, unique rhombic spectrum, resulting from transitions within the $\pm 1 / 2$ ground-state Kramers'

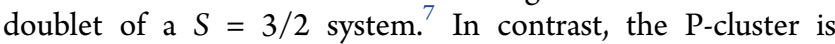
diamagnetic in the dithionite-reduced form $\left(\mathrm{P}^{\mathrm{N}}\right)$ and exhibits a weak resonance at $g=12$ in the oxidized form $\left(\mathrm{P}^{\mathrm{ox}}\right)$. $^{8,9}$ The reported EPR spectra of the FeMo-cofactor under turnover conditions include three spin systems called $1 \mathrm{a}, 1 \mathrm{~b}$, and $1 \mathrm{c} .^{10-12}$ $1 \mathrm{a}$ is the resting state $\left(\mathrm{E}_{0}\right)$, and $1 \mathrm{~b}$ and $1 \mathrm{c}$, which are in equilibrium with $1 \mathrm{a},{ }^{12}$ are attributed to $\mathrm{E}_{2}$ and are thought to represent different states of the FeMo-cofactor during turnover. More specifically, 1c has been suggested to result from protonation of the FeMo-cofactor. ${ }^{11}$ The $\mathrm{E}_{1}$ state is EPR-silent.

The FeMo-cofactor (Figure 1) exhibits approximate $C_{3 v}$ symmetry, with the core provided by a trigonal prism of six Fe atoms (Fe2-7) surrounding an interstitial carbon. ${ }^{13-15}$ Each face of the trigonal prism is bridged by one of three "belt" $S$ labeled S2B, S3A and S5A. Crystallographic evidence for turnover-dependent rearrangements of belt sulfurs is demonstrated by the reversible displacement of S2B upon $\mathrm{CO}$ inhibition. ${ }^{16}$ Se from selenocyanate may also substitute S2B. ${ }^{17}$ In the presence of substrate and under turnover conditions, interchange of the belt sulfurs was established such that Se originally at S2B migrates to S5A and S3A before ultimately exiting the FeMo-cofactor. ${ }^{17}$ Intriguingly, the S2B site displaced

Received: June 1, 2017

Published: July 10, 2017 


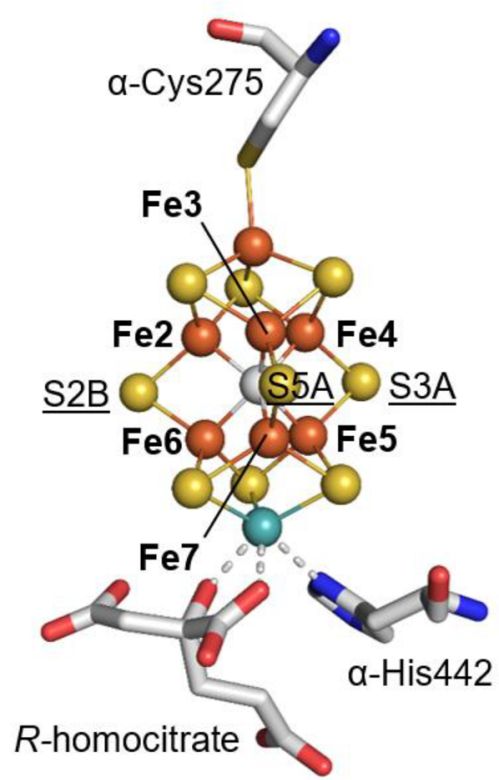

Figure 1. Structure of the FeMo-cofactor. The atoms of the cluster are shown in spheres and colored by element (Fe, orange; S, yellow; $\mathrm{C}$, gray; Mo, cyan). Fe sites in the trigonal prism around the interstitial carbon are labeled with bold print. Belt $S$ are also labeled and underlined. Coordinating residues and the $R$-homocitrate are shown in sticks and colored by element (C, gray; $\mathrm{O}$, red; N, blue).

by $\mathrm{CO}$ bridges $\mathrm{Fe} 2$ and $\mathrm{Fe} 6$, which have been shown to be more oxidized in the resting state, ${ }^{18}$ suggesting that their reduction is critical for ligand binding at this site.

There is still a high level of uncertainty in the mechanistic description of biological nitrogen fixation, including possible structural rearrangements in the FeMo-cofactor. The challenge has been to generate significant populations of higher $\mathrm{E}_{n}$ states competent for substrate binding. As formation of these states is associated with proton uptake, we reasoned that by studying the $\mathrm{MoFe}$ protein at low $\mathrm{pH}$ (high proton concentration), features of the active site that are characteristic of more highly reduced forms might be stabilized through Le Chatelier's principle. The effects of low $\mathrm{pH}(\mathrm{pH} \leq 5)$ on the X-ray structure and EPR spectra of the MoFe protein have not to our knowledge been detailed, likely as it has been reported that the MoFe protein is inactivated below $\mathrm{pH}$ 6.2. ${ }^{19}$ However, our study shows that impacts to the atomic and electronic structure are reversible between $\mathrm{pH} 4.5$ and $\mathrm{pH} 8$ under the tested experimental conditions.

In this study, we examine the two phylogenetically distinct nitrogenase MoFe proteins from Azotobacter vinelandii (Av1) and Clostridium pasteurianum ( $\mathrm{Cp} 1$ ), which have a sequence identity of $\sim 36 \% .{ }^{20}$ Working with Cp1 and Av1, we combine a structural approach with EPR spectroscopy to examine the atomic and electronic structure of $\mathrm{MoFe}$ proteins at $\mathrm{pH} 5$, where the proton concentration is $2-3$ orders of magnitude greater than that of typical enzyme activity measurements. Changes occurring in the $\mathrm{MoFe}$ protein at low $\mathrm{pH}$ might therefore provide crucial information about the atomic and electronic structure of the protein at an early stage of substrate reduction.

\section{RESULTS AND DISCUSSION}

Over the $\mathrm{pH}$ range between 4.5 and 5.8, X-ray crystal structures of $\mathrm{Cp} 1$ and Av1 (Table 1) reveal structural rearrangements near the Fe3,4,5,7 face of the FeMo-cofactor (Figure 2) that are fully reversible upon returning to $\mathrm{pH} \sim 8$. For these studies, the purified protein was resuspended in a low $\mathrm{pH}$ tribuffer system, ${ }^{21}$ allowing the $\mathrm{pH}$ of the protein solution to be varied from $\mathrm{pH} 2$ to $\mathrm{pH} 7$ with minimal variation in the ionic strength and buffer components. Av1 and Cp1 exhibit a partially and fully occupied low $\mathrm{pH}$ conformer, respectively, when $\mathrm{pH} \leq 5$. We determined the $\mathrm{pH} 5$ structures of $\mathrm{Cp} 1$ and Av1 at resolutions of 1.85 and $2.30 \AA$, PDB IDs 5VPW and 5VQ4, respectively. At $\mathrm{pH} \sim 6.5, \mathrm{Cp} 1$ exhibits both conformations; the PDB ID for this structure is $5 \mathrm{VQ} 3$.

The conversion of the $\mathrm{pH} \sim 8$ conformer to the low $\mathrm{pH}$ conformer under different $\mathrm{pH}$ and ionic strength conditions was explored in $\mathrm{Cp} 1$ over a large number of conditions. It was found that higher ionic strength contributes to increased occupancy of the low $\mathrm{pH}$ conformer, which occurred at $\mathrm{pH} 5.8$ or lower, depending on ionic strength. In view of the dependence of conformer occupancy on $\mathrm{pH}$ and ionic strength as well as the challenges of measuring $\mathrm{pH}$ in small volumes

\section{Table 1. X-ray Crystallographic Data Collection and Refinement Statistics}

\begin{tabular}{|c|c|c|c|}
\hline & Av1 at pH 5 (5VQ4) & $\mathrm{Cp} 1$ at $\mathrm{pH} 5(5 \mathrm{VPW})$ & $\mathrm{Cp} 1$ at $\mathrm{pH} 6.5$ (5VQ3) \\
\hline \multicolumn{4}{|l|}{ Data Collection } \\
\hline space group & $\mathrm{P} 2_{1}$ & $\mathrm{P} 2_{1}$ & $\mathrm{P} 2_{1}$ \\
\hline cell dimensions & $81.31,128.9,108.4$ & $69.62,146.3,116.7$ & $69.48,148.0,116.7$ \\
\hline$a, b, c(\AA) ; \alpha, \beta, \gamma(\operatorname{deg})$ & $90,110.9,90$ & $90,103.6,90$ & $90,103.5,90$ \\
\hline resolution $(\AA)$ & $39.54-2.30(2.30-2.34)^{a}$ & $39.20-1.85(1.88-1.85)^{a}$ & $39.83-1.75(1.75-1.72)^{a}$ \\
\hline$R_{\text {merge }}$ & $0.174(0.720)^{a}$ & $0.105(0.684)^{a}$ & $0.079(0.682)^{a}$ \\
\hline$I / \sigma(I)$ & $9.2(3.1)^{a}$ & $11.6(2.5)^{a}$ & $13.5(2.9)^{a}$ \\
\hline completeness (\%) & $98.8(99.4)^{a}$ & $98.4(95.4)^{a}$ & $98.4(98.4)^{a}$ \\
\hline no. unique reflections & $91,309(4,321)^{a}$ & $189,858(1,197)^{a}$ & $238,230(11,876)^{a}$ \\
\hline redundancy & $6.7(7.1)^{a}$ & $6.5(6.2)^{a}$ & $6.8(7.0)^{a}$ \\
\hline \multicolumn{4}{|l|}{ Refinement } \\
\hline$R_{\text {work }} / R_{\text {free }}$ & $0.176 / 0.226$ & $0.167 / 0.201$ & $0.159 / 0.185$ \\
\hline average B-factor & 24.0 & 30.0 & 29.0 \\
\hline rms bond lengths $(\AA)$ & 0.011 & 0.012 & 0.013 \\
\hline rms bond angles (deg) & 1.39 & 1.41 & 1.52 \\
\hline
\end{tabular}

${ }^{a}$ Highest resolution shell is shown in parentheses. 

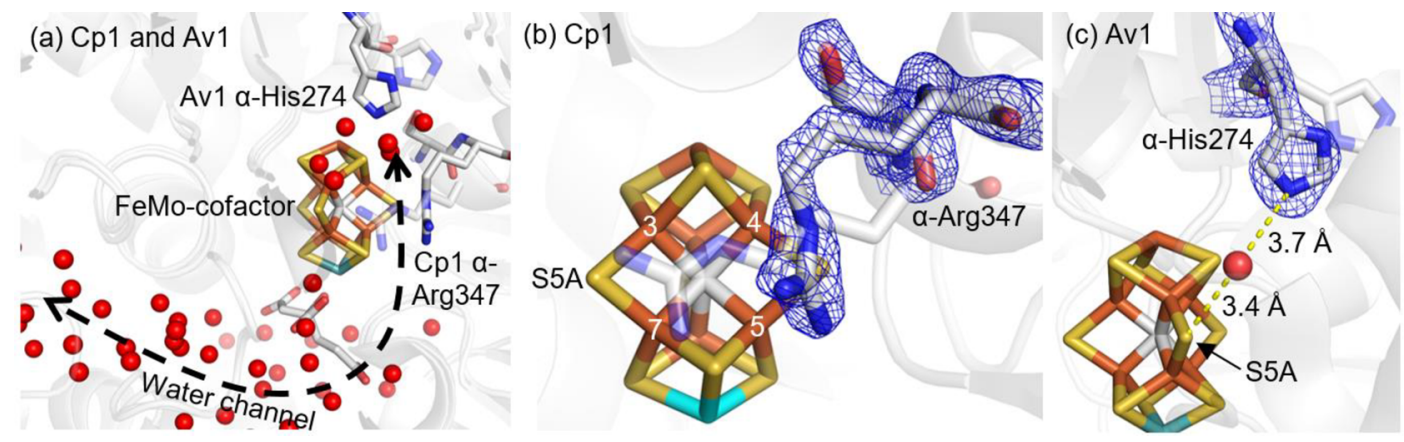

Figure 2. (a) Overview of the structural rearrangements observed at low $\mathrm{pH}$ at the active sites of $\mathrm{Cp} 1$ and Av1. Both changes occur on the Fe3,4,5,7 face of the FeMo-cofactor, which is the same face that is exposed to water molecules and connects to the interstitial water channel illustrated for Cp1 (dashed black line). (b) In Cp1, a peptide flip occurs between $\alpha$-Arg347 and $\alpha$-Ser346, and the Arg side chain relinquishes its hydrogen bond with S5A. (c) In Av1, the $\alpha$-His274 side chain swings closer to the FeMo-cofactor and displaces a water molecule; two water molecules fill the former $\alpha$ His274 side chain position. The $\alpha$-His274 coordinates to S5A of the FeMo-cofactor through a hydrogen-bond bridge with a water molecule. In all images, transparent gray represents the physiological $\mathrm{pH}$ structures. Nontransparent gray sticks show the low $\mathrm{pH}$ structural changes. The FeMocofactor and $\mathrm{pH}$-affected residues are displayed as sticks and colored by element (yellow, $\mathrm{S}$; orange, $\mathrm{Fe}$; , cyan, Mo; gray, $\mathrm{C}$ ). Water molecules are represented as red spheres. The blue meshes in (b) and (c) show the electron density maps of the pH-affected residues contoured to 2.0 and $1.5 \sigma$, respectively.

around crystals and the uncertainties in extrapolating $\mathrm{pH}$ values measured to room temperature to the cryogenic temperatures used for crystallography and EPR, for simplicity, the acidinduced Av1 and Cp1 structural rearrangements are herein referred to as the low $\mathrm{pH}$ or $\mathrm{pH} 5$ conformers. The $\mathrm{pH}$ range of optimal activity ${ }^{19}(\sim 7.5-8)$ will be referred to as physiological $\mathrm{pH}$.

At low $\mathrm{pH}$ in $\mathrm{Cp} 1$, a peptide flip ${ }^{22}$ occurs between $\alpha$-Ser346 and $\alpha$-Arg347 (corresponding to Av1 residues $\alpha$-Leu358 and $\alpha$ Arg359, respectively), causing the arginine to reposition away from the Fe3,4,5,7 face of the FeMo-cofactor (Figures $2 \mathrm{~b}$ and 3). Notably, this low $\mathrm{pH}$ rearrangement causes changes in hydrogen-bonding interactions between side chain atoms of $\alpha$ -

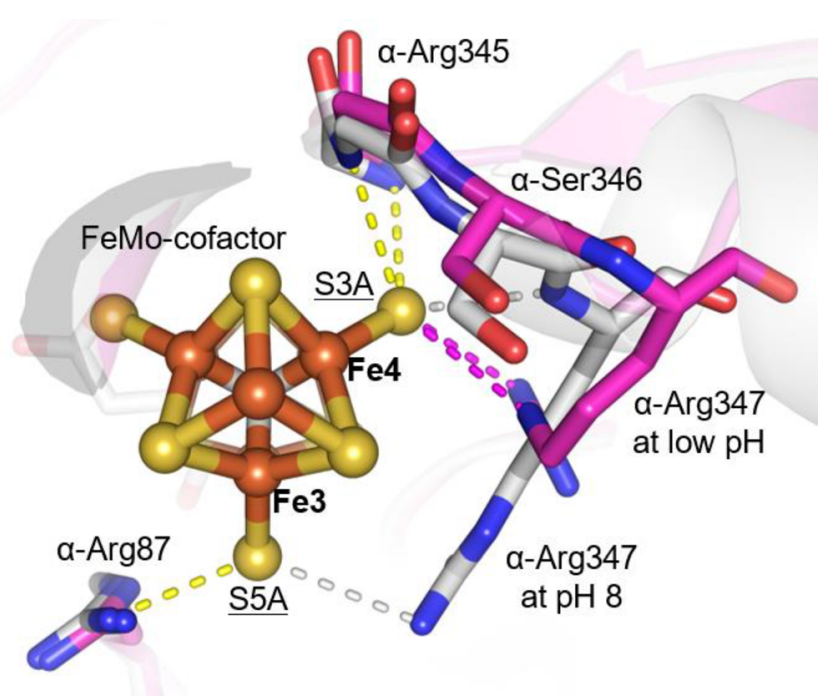

Figure 3. Structure of the $\mathrm{Cp} 1 \mathrm{FeMo}$-cofactor as viewed down the $C_{3}$ axis. $\alpha$-Arg347 at $\mathrm{pH} 8$ (gray) and low $\mathrm{pH}$ (magenta) is shown in sticks. Contacts with the FeMo-cofactor at $\mathrm{pH} 8$ and low $\mathrm{pH}$ are indicated with dashed lines (low $\mathrm{pH}$ contacts, gray; $\mathrm{pH} 8$ contacts, magenta; $\mathrm{pH}$-independent contacts, yellow). All contact distances are $\leq 3.5 \AA$. The atoms of the cluster are shown in spheres and colored by element (Fe, orange; $\mathrm{S}$, yellow; $\mathrm{C}$, gray; Mo, cyan). Relevant Fe and $\mathrm{S}$ atoms are labeled. Coordinating residues and the $R$-homocitrate are shown in sticks and colored by element (C, gray; $\mathrm{O}$, red; $\mathrm{N}$, blue).
Arg347 and S3A and S5A in Cp1 (Figure 3): S5A loses its only hydrogen bond to $\mathrm{NH} 1$; $\mathrm{S} 3 \mathrm{~A}$ loses its contact with the backbone amide $\mathrm{NH}$; and $\mathrm{S} 3 \mathrm{~A}$ gains contacts with $\mathrm{NH} 1$ and $\mathrm{NE}$ of the arginine side chain. In Av1 at low $\mathrm{pH}$, the side chain of Av1 $\alpha$-His274 (adjacent to the FeMo-cofactor ligand $\alpha$ Cys275 and corresponding to Cp1 $\alpha$-Gln261) moves closer to the FeMo-cofactor and displaces a water molecule. At this new position, a water molecule bridges the Av1 $\alpha$-His274 side chain and S5A of the FeMo-cofactor (Figure 2c). Of the two residues most affected by low $\mathrm{pH}$ in $\mathrm{Cp} 1$ and Av1, Cp1 $\alpha$-Arg347 is invariant in all nitrogenases, whereas Av1 $\alpha$-His274 is variant and exists as a glutamine residue in $\mathrm{Cp} 1 .^{20}$ Mutagenesis of these residues in Av1 significantly reduces substrate reduction, ${ }^{23,24}$ and $\alpha$-His 274 has been implicated in FeMo-cofactor insertion during Av1 assembly. ${ }^{25}$

The low $\mathrm{pH}$ structural rearrangements only occur on the face of the FeMo-cofactor that is exposed to water molecules $(\mathrm{Fe} 3,4,5,7)$, potentially implicating this water pool (and likely the water channel that connects this pool to the protein surface) in proton transport between the active site and the exterior. $^{26-28}$ Additionally, there is slight movement $(<1 \AA)$ of the $\mathrm{C} 1$ carboxyl of the $R$-homocitrate away from $\alpha$-Gln 191 in Av1. A previously reported structure of Av1 at $\mathrm{pH} 9.5$ shows slight movement of the C1 carboxyl toward $\alpha$-Gln $191,{ }^{29}$ which, in combination with results reported herein, indicates conformational flexibility in the $\mathrm{C} 1$ arm of the $R$-homocitrate in response to $\mathrm{pH}$, possibly due to change in protonation state of the carboxylate group.

The low $\mathrm{pH}$ conformational changes could be triggered by proton binding to either the protein (possibly the side chains of His, Glu and Asp) as well as water and/or sites on the FeMocofactor such as the sulfurs and/or homocitrate. Without direct visualization of hydrogens, it is not possible to establish unambiguously which atoms are protonated to trigger the observed structural rearrangements. After close examination of the FeMo-cofactor and active site residues in the low and physiological $\mathrm{pH}$ structures, we see no obvious indicators for protonation of side chains. It is also conceivable that protonation could be coupled to anion binding, such as buffer or counterion components in the buffer, but we see no evidence for this possibility, based on the absence of new or shifted peaks in the solvent region. This leaves the possibility 
(a)

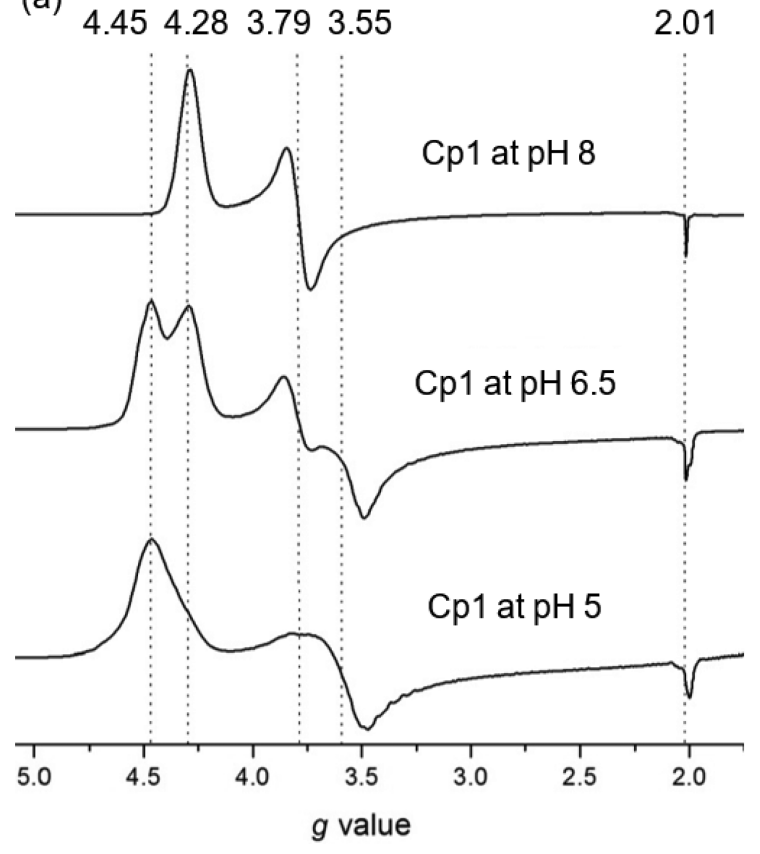

(b)

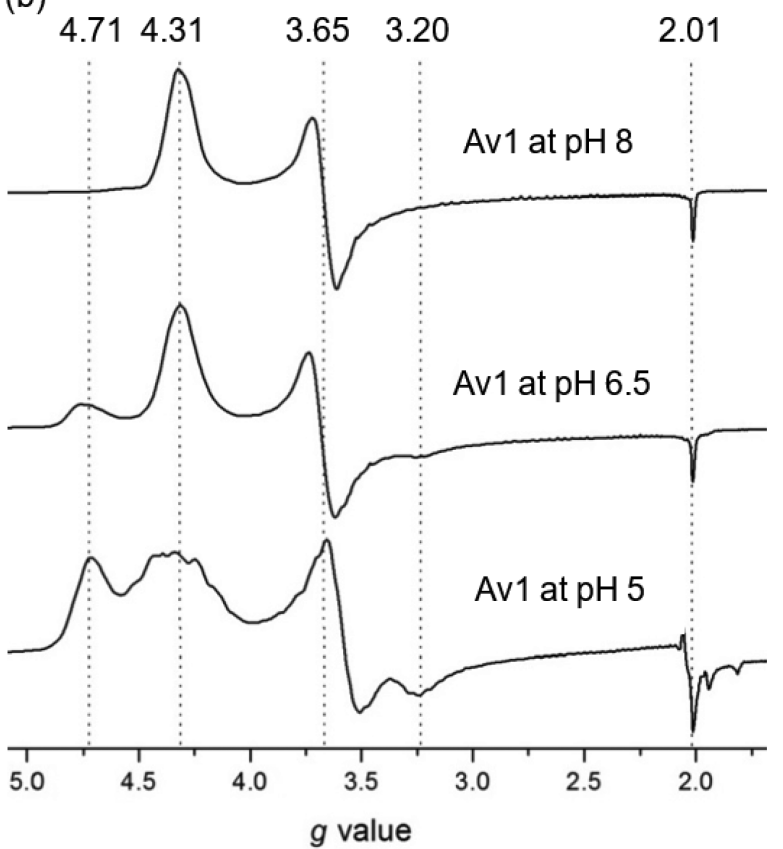

Figure 4. (a) Comparison of the EPR spectra of Cp1 at pHs 8, 6.5, and 5. The same is shown in (b) for Av1.

Table 2. Summary of EPR Data

\begin{tabular}{|c|c|c|c|c|}
\hline protein & & $g_{\text {eff }}$ values ${ }^{a}$ & $E / D$ & refs \\
\hline \multirow{2}{*}{ resting state $\mathrm{Cp} 1$ at $\mathrm{pH} 8$} & & $4.28,3.79,2.01$ & 0.041 & \multirow{2}{*}{$\begin{array}{l}\text { this work } \\
44\end{array}$} \\
\hline & & $4.29,3.76,2.01$ & not reported & \\
\hline \multirow{2}{*}{$\mathrm{Cp} 1$ at $\mathrm{pH} 6.5$} & & $4.28,3.79,2.01$ (physiological pH spin system) & 0.041 & \multirow{2}{*}{ this work } \\
\hline & & $4.45,3.55,2.00$ (low $\mathrm{pH}$ spin system) & 0.077 & \\
\hline $\mathrm{Cp} 1$ at $\mathrm{pH} 5$ & & $4.45,3.60,2.00$ & 0.070 & this work \\
\hline \multirow{2}{*}{ Avl resting state at $\mathrm{pH} 8$} & & $4.30,3.65,2.01$ & 0.053 & this work \\
\hline & & $4.31,3.65,2.01$ & 0.053 & 45 \\
\hline \multirow{4}{*}{ Avl under turnover conditions at $\mathrm{pH} 8$} & la & $4.32,3.66,2.01$ & not reported & $10,12,46$ \\
\hline & $1 b$ & $4.21,3.76,1.97$ & not reported & $11,12,46$ \\
\hline & $1 b$ & $4.27,3.73,2.02$ & not reported & 10 \\
\hline & $1 \mathrm{c}$ & 4.7 or $4.69, \sim 3.2-3.4, \sim 2.0$ & not reported & $10-12,47$ \\
\hline \multirow{2}{*}{ Avl at $\mathrm{pH} 6.5$} & & $4.31,3.67,2.01$ (physiological pH spin system) & 0.053 & \multirow{2}{*}{ this work } \\
\hline & & $4.72,3.30,2.01$ (low $\mathrm{pH}$ spin system) & 0.124 & \\
\hline \multirow{2}{*}{ Av1 at $\mathrm{pH} 5$} & & $4.32,3.57,2.01$ (physiological $\mathrm{pH}$ spin system) & 0.064 & \multirow{2}{*}{ this work } \\
\hline & & $4.71,3.30,2.01$ (low pH spin system) & 0.120 & \\
\hline
\end{tabular}

that the low $\mathrm{pH}$ rearrangements may reflect protonation of water and/or the FeMo-cofactor. Other than the R-homocitrate, the sulfurs represent the most likely site of protonation on the cofactor based on the $\mathrm{pH}$ titration properties of synthetic and protein-based clusters. ${ }^{30-32}$

Following structural characterization by X-ray crystallography, EPR spectroscopy was performed on Cp1 and Av1 in solution at pHs 8, 6.5, and 5 (Figure 4). From simulations, the effective $g$ values and $E / D$ ratios were determined (Table 2 and Supplementary Figure 1). In both $\mathrm{Cp} 1$ and Av1, low $\mathrm{pH}$ conditions induce a second rhombic spin system with higher rhombicity compared to the resting state spin system at $\mathrm{pH} 8$. Line broadening is also observed in the low $\mathrm{pH}$ spectra, reminiscent of the EPR spectra of Cp1 FeMo-cofactor extracted in $\mathrm{N}$-methylformamide. ${ }^{33}$ The two spin systems are in equilibrium with each other (Figure 4). All low pH EPR changes are reversible in both $\mathrm{Cp} 1$ and Av1 (Supplementary Figure 2). Power sweeps at the different $\mathrm{pHs}$ on Av1 and Cp1 show similar changes in peak area with change in power, indicating similar relaxation behavior of the spin systems at both low and physiological pHs (Supplementary Figure 3). 
(a)
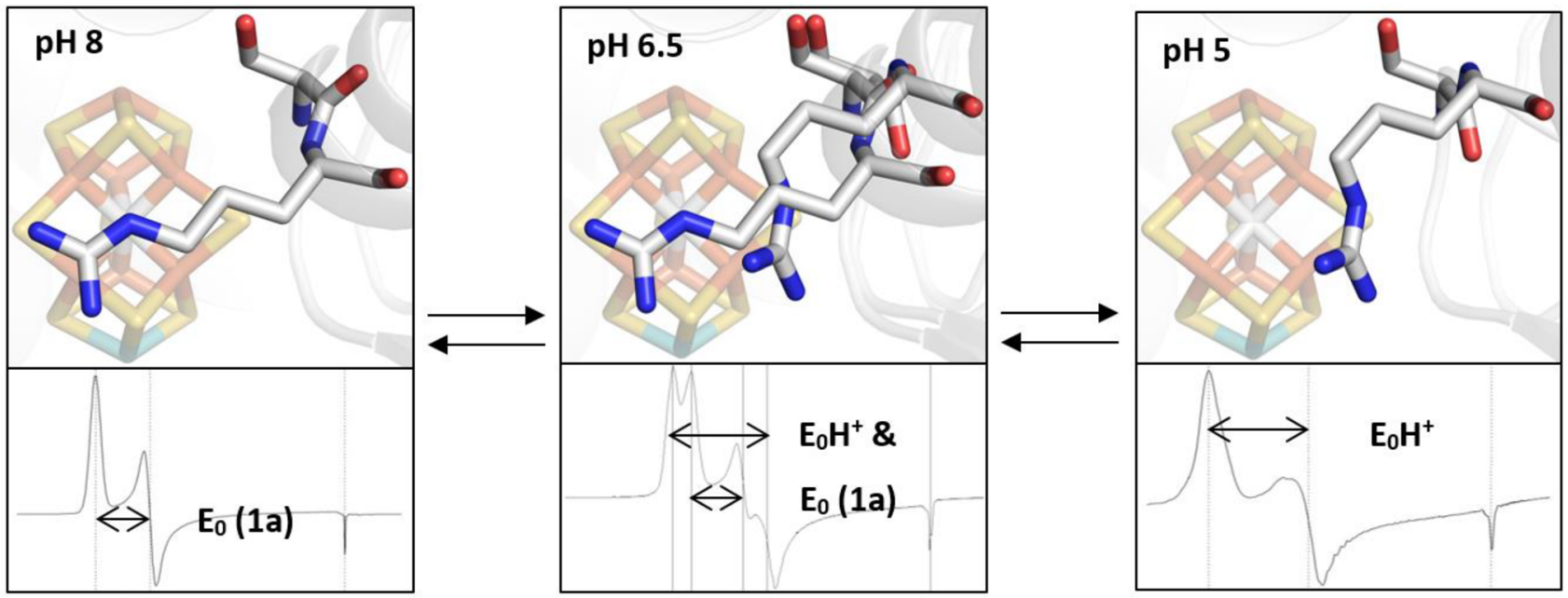

(b)

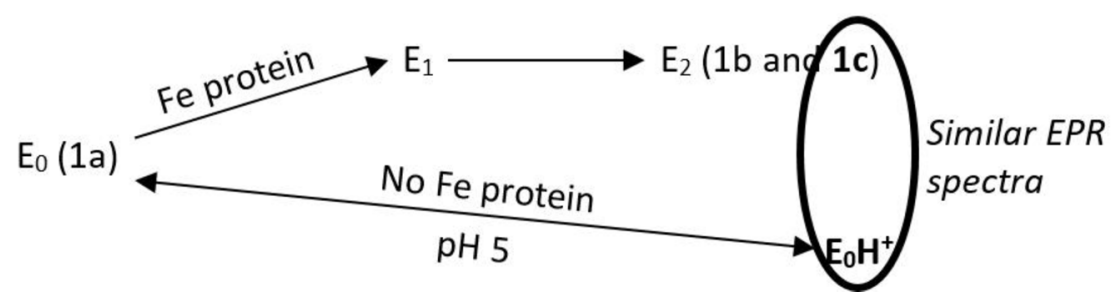

Figure 5. (a) A summary of the $\mathrm{Cp} 1$ data presented in this manuscript. At $\mathrm{pH} 8$, the typical resting state X-ray diffraction structure and EPR signal are observed. At $\mathrm{pH} 5$, a peptide flip and repositioning of the $\alpha$-Arg357 side chain away from the Fe3,4,5,7 face of the FeMo-cofactor is observed as well as a $S=3 / 2$ spin system with zero-field splitting parameters similar to those reported for one of the signals observed in the $\mathrm{E}_{2}$ state. At intermediate $\mathrm{pH}$, both structural conformations and EPR spin systems are observed. The EPR signals and X-ray structures are reversible and correlated. (b) The 1c peak has been attributed to the $\mathrm{E}_{2}$ state and is hypothesized to result from protonation of the FeMo-cofactor. Our experimental conditions include only a proton source and not an electron source, so it is unlikely that these conditions achieve a reduced state, such as $\mathrm{E}_{2}$. Consequently, we propose that our low $\mathrm{pH}$ conditions yield a protonated resting state, which we call " $\mathrm{E}_{0} \mathrm{H}^{+”}$.

The Av1 low $\mathrm{pH}$ spin system is an $S=3 / 2$ system with zerofield splitting parameters similar to those reported for the $1 \mathrm{c}$ spin system. The $1 \mathrm{c}$ spin system emerges after $1 \mathrm{~b}$, putatively during the accumulation of electrons from the $\mathrm{E}_{0}$ to $\mathrm{E}_{2}$ state. ${ }^{10}$ The $1 \mathrm{c}$ and $1 \mathrm{~b}$ systems form under turnover conditions (ATP regenerating system, Fe protein, and reductant) but without added substrate beyond $\mathrm{H}^{+}$. 1c was never observed without $1 \mathrm{~b}$ present, ${ }^{10}$ and these signals relax with the same decay constant. ${ }^{12}$ Studies on the EPR of states more reduced than $\mathrm{E}_{0}$ suggest that $1 \mathrm{c}$ is a result of protonation of the FeMocofactor. $^{11}$

The equivalence between the crystal structure and the protein in solution was accomplished by measuring the EPR spectrum of a solution and polycrystalline protein sample under the same conditions used for the low $\mathrm{pH}$ X-ray crystallographic experiments (Supplementary Figure 4). The resulting spectra exhibit the same features, thereby confirming that the low $\mathrm{pH}$ structural changes observed by X-ray crystallography correlate to the low $\mathrm{pH}$ electronic changes observed by EPR spectroscopy.

Because our experimental conditions do not include the $\mathrm{Fe}$ protein and ATP regenerating system, and because all data obtained with and without dithionite are comparable, a net flow of electrons to the FeMo-cofactor is unlikely in our low $\mathrm{pH}$ experimental conditions. Therefore, we conclude that the low $\mathrm{pH}$ state is a protonated resting state. We call it " $\mathrm{E}_{0} \mathrm{H}^{+}$, following the Lowe-Thorneley naming scheme. We would like to emphasize that this name is a generic designation for a protonated form of the resting state; we cannot determine the number of protons added to the FeMo-cofactor at low $\mathrm{pH}$. Figure 5 depicts a summary of the relationships between different forms of the resting state, together with their major Xray and EPR features.

\section{CONCLUSION}

The MoFe protein exhibits $\mathrm{pH}$-dependent structural and electronic rearrangements in close proximity to the active site. The low $\mathrm{pH}$ structural rearrangements involve residues $\alpha$ Arg347 from Cp1 and $\alpha$-His274 from Av1, both of which participate in hydrogen-bond networks with FeMo-cofactor belt sulfurs. The structural and electronic changes are reversible with $\mathrm{pH}$ and directly correlated, the latter of which was demonstrated by performing EPR spectroscopy on polycrystalline samples. Given the observed structural rearrangements and the absence of a net flow of electrons through nitrogenase at low $\mathrm{pH}$ without the Fe-protein, we conclude from this data that reversible protonation of the resting state of the FeMo-cofactor occurs at low $\mathrm{pH}$ to generate " $\mathrm{E}_{0} \mathrm{H}^{+}$." The most likely sites of protonation on the resting state FeMo-cofactor are belt sulfurs S3A and S5A. Given the similarity of EPR spectral features of the low $\mathrm{pH}$ Av1 spin system to that observed for 1c, which is one of the two spin systems assigned to $E_{2}$, the reversible protonation of the resting state discussed herein may be similar to protonation events occurring in the $E_{2}$ state of catalytic turnover.

This study demonstrates the advantage of comparing more than one species of nitrogenase MoFe protein, despite having the same cofactor structures, when addressing the mechanism 
of substrate reduction. This is supported by the fact that the low $\mathrm{pH}$ structural and electronic changes of $\mathrm{Cp} 1$ and $\mathrm{Av1}$ are similar but not identical: the low $\mathrm{pH}$ structural changes are different but occur on the same face of the FeMo-factor, and the low $\mathrm{pH}$ spin systems show similar but not identical $g$ values and $E / D$ ratios. In both $C p 1$ and $A v 1$, however, the structural data suggest protonation of the resting state may occur at one of the two belt sulfurs that are not replaced by $\mathrm{CO}$ or Se, which may facilitate rearrangements of the cofactor during turnover.

\section{EXPERIMENTAL SECTION}

Cell Growth and Protein Purification. Av1 and $\mathrm{Cp} 1$ protein were obtained using cell growth and protein purification procedures previously described. ${ }^{34,35}$

Crystallization. Protein stocks consisted of $30-35 \mathrm{mg} / \mathrm{mL}$ protein in a solution of $200 \mathrm{mM}$ sodium chloride, $50 \mathrm{mM}$ Tris/ $\mathrm{HCl}$ at $\mathrm{pH}$ 7.75 , and $5 \mathrm{mM}$ sodium dithionite. Protein crystals were grown in 24well plates using the sitting-drop method with a 1:1 ratio of protein stock to reservoir solution at room temperature in an anaerobic chamber with an atmosphere of $\sim 95 \%$ argon and $\sim 5 \%$ hydrogen. All solutions were made anaerobic through a series of vacuum and argon cycles. The reservoir solution for Av1 crystals consisted of doubledistilled water, $15 \%$ polyethylene glycol (MW $4000 \mathrm{~g} / \mathrm{mol}$, Hampton Research), 0.5-0.8 M sodium chloride (VWR), $0.2 \mathrm{M}$ imidazole/ malate at $\mathrm{pH} 8$ (Sigma-Aldrich), and $5 \mathrm{mM}$ sodium dithionite (J.T. Baker). The reservoir solution for Cp1 crystals consisted of doubledistilled water, 13.5-14\% polyethylene glycol (MW $3350 \mathrm{~g} / \mathrm{mol}$, Hampton Research), 0.3-0.5 M magnesium chloride (Mallinckrodt), $0.08 \mathrm{M}$ Tris $/ \mathrm{HCl}$ at $\mathrm{pH} 8$ (Fisher Scientific), and $5 \mathrm{mM}$ sodium dithionite. Av1 and $\mathrm{Cp} 1$ crystals of block morphology formed overnight.

Tribuffer Preparation. A tribuffer consists of three different buffers, such that the buffering capacity extends over a large $\mathrm{pH}$ range while maintaining a nearly constant ionic strength. We created a tribuffer from $0.05 \mathrm{M}$ glycylglycine $\left(\mathrm{p} K_{\mathrm{a}}=3.14\right.$, Acros Organics), 0.05 $\mathrm{M}$ acetic acid $\left(\mathrm{p} K_{\mathrm{a}}=4.76\right.$, Sigma-Aldrich), $0.10 \mathrm{M}$ Bis-Tris $\left(\mathrm{p} K_{\mathrm{a}}=\right.$ 6.46, Sigma) based on work by Ellis and Morrison. ${ }^{21}$ The tribuffer was adjusted to $\mathrm{pHs} 6,5,4,3$, and 2 using $\mathrm{HCl}$ and maintained an ionic strength of $\sim 0.1 \mathrm{M}$.

$\mathrm{pH}$ Measurements. The $\mathrm{pH}$ of solutions surrounding crystals was measured using litmus paper at room temperature. Since the experimental conditions were $100 \mathrm{~K}$ (X-ray crystallography) and 4$8 \mathrm{~K}$ (EPR), the $\mathrm{pH}$ of the samples under cryogenic conditions will likely be greater than measured at room temperature. ${ }^{36}$

X-ray Sample Preparation. A low $\mathrm{pH}$ solution was made according to the recipe for each well's reservoir solution except that a tribuffer at low $\mathrm{pH}$ was substituted for Tris/ $\mathrm{HCl}(\mathrm{Cp} 1)$ or imidazole/ malate (Av1) at $\mathrm{pH} 8$. Ten $\mu \mathrm{L}$ of low $\mathrm{pH}$ solution was added to each well containing crystals as well as $1 \mu \mathrm{L}$ of 2-methyl-2,4-pentanediol (cryo-protectant, Acros Organics). Also, three drops of Fomblin Y 16/ 6 mineral oil (Sigma-Aldrich) were added to the top of each crystal drop for additional cryo-protection. Crystals soaked for at least $5 \mathrm{~min}$ in the low $\mathrm{pH}$ solution before flash freezing in liquid nitrogen on nylon loops. The percentage of protein molecules exhibiting the low $\mathrm{pH}$ structural rearrangements was not impacted by soaking duration, provided that the crystals soaked for at least $5 \mathrm{~min}$ before freezing. Because the crystal wells contain Tris/ $\mathrm{HCl}$ at $\mathrm{pH} 8$ as part of the crystallization recipe, the actual $\mathrm{pH}$ of the solution that the crystals soaked in upon addition of low $\mathrm{pH}$ buffer was higher than the $\mathrm{pH}$ of the added tribuffer. To illustrate, in order to soak a crystal at $\mathrm{pH} 5$, tribuffer at $\mathrm{pH} 2$ must be added to the crystallization well, since Tris/ $\mathrm{HCl}$ at $\mathrm{pH} 8$ is also present. Attempts to transfer crystals from the crystal well to a low $\mathrm{pH}$ buffer resulted in crystal cracking.

To check for structural reversibility in the crystallized state, crystals were soaked at low $\mathrm{pH}$ as described for $10 \mathrm{~min}$, transferred to a well containing fresh reservoir solution at $\mathrm{pH} 8$, and then flash frozen in liquid nitrogen after soaking at $\mathrm{pH} 8$ for $5 \mathrm{~min}$.
X-ray Data Collection and Refinement. Diffraction data for Cp1 were collected remotely from the Stanford Synchrotron Radiation Lightsource (SSRL) on beamline 12-2 with a DECTRIS Pilatus $6 \mathrm{M}$ detector. Reference sets of 1440 diffraction images were collected at $12657.99 \mathrm{eV}$ with an oscillation angle of $0.25^{\circ}$ over $360^{\circ}$ rotation. Diffraction data for Av1 were collected in-house on a Rigaku MicroMax 007-HF X-ray generator with a Rigaku RAXIS-IV++ detector. All data sets were integrated with the XDS program package. ${ }^{37}$ Scaling was carried out with the CCP4 suite, ${ }^{38}$ and phasing was determined by molecular replacement against high resolution Av1 (PDB ID 3U7Q) and Cp1 (PDB ID 4WES) structures using PHASER. ${ }^{13,35}$ Initial refinement was carried out with $\mathrm{CNS},{ }^{39}$ and alternative conformations and isotropic B-factors were refined with REFMAC5. ${ }^{40,41}$ All figures were made in PyMOL. ${ }^{42}$

EPR Sample Preparation. After solubility tests, the following solution was chosen for low $\mathrm{pH}$ EPR studies: $100 \mathrm{mM}$ tribuffer at $\mathrm{pH}$ 2, $500 \mathrm{mM} \mathrm{MgCl}_{2}$, and $5 \mathrm{mM}$ sodium dithionite. To prepare the EPR samples, protein stock was concentrated $50 \%$ and then diluted with the low pH EPR solution. Samples were allowed to equilibrate for at least $30 \mathrm{~min}$ prior to freezing in liquid nitrogen. $200 \mu \mathrm{L}$ of each sample $(\sim 30 \mathrm{mg} / \mathrm{mL})$ was transferred to an EPR tube in an anaerobic tent. The samples were carefully frozen in liquid nitrogen inside the anaerobic tent and then stored in a liquid nitrogen dewar until use.

After obtaining an EPR spectrum of the low $\mathrm{pH}$ Av1 and $\mathrm{Cp} 1$ samples, the samples were thawed and transferred to $\mathrm{pH} 8$ by repeatedly concentrating the protein solution and then diluting it with the protein storage solution $(200 \mathrm{mM} \mathrm{NaCl}, 50 \mathrm{mM}$ Tris at $\mathrm{pH} 8$, and $5 \mathrm{mM}$ sodium dithionite). EPR spectroscopy was performed on the protein resuspended at $\mathrm{pH} 8$ to check for reversibility.

To test if the structural changes observed by X-ray crystallography are related to changes observed in the solution state by EPR, polycrystalline samples of Av1 and Cp1 were made by collecting crystals from six plates of seeded crystals, crushing the crystals, and transferring them to low $\mathrm{pH}$ solutions used for the $\mathrm{X}$-ray studies: (Av1) $15 \%$ PEG $4000 \mathrm{~g} / \mathrm{mol}, 0.5 \mathrm{M} \mathrm{MgCl}_{2}, 0.1 \mathrm{M}$ tribuffer at $\mathrm{pH} 2,5$ $\mathrm{mM}$ sodium dithionite; (Cp1 at $\mathrm{pH} 6.5$ ) $14 \%$ PEG $3350 \mathrm{~g} / \mathrm{mol}, 0.3 \mathrm{M}$ $\mathrm{MgCl}_{2}, 0.02 \mathrm{M}$ tribuffer at $\mathrm{pH} 2,5 \mathrm{mM}$ sodium dithionite; (Cp1 at $\mathrm{pH}$ 5) $13.5 \%$ PEG $3350 \mathrm{~g} / \mathrm{mol}, 0.5 \mathrm{M} \mathrm{MgCl}_{2}, 0.08 \mathrm{M}$ tribuffer at $\mathrm{pH} 2,5$ $\mathrm{mM}$ sodium dithionite.

EPR Spectroscopy. EPR spectra were recorded with an X-band Bruker EMX spectrometer equipped with an ER 4119HS cavity. The Bruker Win-EPR software suite version 3.0 was used. Variabletemperature experiments were performed with an Oxford (ESR900) helium cryostat (temperature range 4-8 K). All spectra were recorded at $9.37 \mathrm{GHz}$ with a microwave power of $1 \mathrm{~mW}$, a modulation amplitude of $2 \mathrm{G}$, and a modulation frequency of $100 \mathrm{kHz}$ at $4 \mathrm{~K}$. For the power sweep data, the power was varied from $0.02 \mathrm{~mW}$ to $20 \mathrm{~mW}$, and the temperature was set to 5 and $8 \mathrm{~K}$ for Av1 and Cp1, respectively. Simulations were performed with the EasySpin software suite (Supplementary Figure 1). ${ }^{43}$ For all simulations, the $S=3 / 2$ real spin system (axial $g$-tensor) and $S=1 / 2$ effective spin system (rhombic $g$-tensor) were matched to the experimental spectra. From the $S=3 / 2$ model, the $E / D$ ratio was determined. From the $S=1 / 2$ model, the effective $g$ values were determined. For spectra exhibiting two spin systems, simulations were calculated by combining two spin systems with their own $E / D$ ratios and $g$ values. The relative weight of the spin systems and line widths were varied by inspection. All parameters for the simulations are provided in Supplementary Table 1.

\section{ASSOCIATED CONTENT}

\section{Supporting Information}

The Supporting Information is available free of charge on the ACS Publications website at DOI: 10.1021/jacs.7b05695.

EPR simulation parameters and spectra are included. The structural model and structure factors have been deposited with the Protein Data Bank (PDB) under accession codes 5VPW, 5VQ3, and 5VQ4 (PDF) 


\section{AUTHOR INFORMATION}

\section{Corresponding Author}

*dcrees@caltech.edu

\section{ORCID $\odot$}

Christine N. Morrison: 0000-0002-4180-8407

Douglas C. Rees: 0000-0003-4073-1185

\section{Funding}

This material is based upon work supported by the National Science Foundation Graduate Research Fellowship (Grant DGE-1144469 to C.N.M.), the National Institute of Health (NIH Grant GM45162 to D.C.R.), and the Howard Hughes Medical Institute (D.C.R.).

Notes

The authors declare no competing financial interest.

\section{ACKNOWLEDGMENTS}

We acknowledge the Gordon and Betty Moore Foundation and the Beckman Institute at Caltech for their generous support of the Molecular Observatory at Caltech. We thank the staff at Beamline 12-2, Stanford Synchrotron Radiation Lightsource (SSRL), operated for the DOE and supported by its OBER and by the NIH, NIGMS (P41GM103393), and the NCRR (P41RR001209). We thank Dr. Angelo Di Bilio for assisting with the EPR experiments, Dr. Lorenz Heidinger for providing a script for EPR simulations, Dr. Paul Oyala for assistance with the EPR simulations and analysis, and Dr. Jens Kaiser, Dr. James B. Howard, Dr. Kathryn Perez, Dr. Helen Segal, Belinda Wenke, and Renee Arias for helpful discussions.

\section{REFERENCES}

(1) Burgess, B. K.; Lowe, D. J. Chem. Rev. 1996, 96, 2983-3012.

(2) Howard, J. B.; Rees, D. C. Proc. Natl. Acad. Sci. U. S. A. 2006, 103, 17088-17093.

(3) Hoffman, B. M.; Lukoyanov, D.; Yang, Z.-Y.; Dean, D. R.; Seefeldt, L. C. Chem. Rev. 2014, 114, 4041-4062.

(4) Hageman, R. V.; Orme-Johnson, W. H.; Burris, R. H. Biochemistry 1980, 19, 2333-2342.

(5) Thorneley, R. N.; Lowe, D. J. Molybdenum Enzymes; Spiro, T. G., Ed.; John Wiley \& Sons: New York, 1985; Vol. 7, pp 221-284.

(6) Wilson, P. E.; Nyborg, A. C.; Watt, G. D. Biophys. Chem. 2001, 91, 281-304.

(7) Münck, E.; Rhodes, H.; Orme-Johnson, W. H.; Davis, L. C.; Brill, W. J.; Shah, V. K. Biochim. Biophys. Acta, Protein Struct. 1975, 400, $32-$ 53.

(8) Surerus, K. K.; Hendrich, M. P.; Christie, P. D.; Rottgardt, D.; Orme-Johnson, W. H.; Münck, E. J. Am. Chem. Soc. 1992, 114, 85798590.

(9) Pierik, A. J.; Wassink, H.; Haaker, H.; Hagen, W. R. Eur. J. Biochem. 1993, 212, 51-61.

(10) Fisher, K.; Newton, W. E.; Lowe, D. J. Biochemistry 2001, 40, 3333-3339.

(11) Fisher, K.; Lowe, D. J.; Tavares, P.; Pereira, A. S.; Huynh, B. H.; Edmondson, D.; Newton, W. E. J. Inorg. Biochem. 2007, 101, 16491656.

(12) Lukoyanov, D.; Yang, Z.-Y.; Duval, S.; Danyal, K.; Dean, D. R.; Seefeldt, L. C.; Hoffman, B. M. Inorg. Chem. 2014, 53, 3688-3693.

(13) Spatzal, T.; Aksoyoglu, M.; Zhang, L.; Andrade, S. L.; Schleicher, E.; Weber, S.; Rees, D. C.; Einsle, O. Science 2011, 334, 940.

(14) Lancaster, K. M.; Roemelt, M.; Ettenhuber, P.; Hu, Y.; Ribbe, M. W.; Neese, F.; Bergmann, U.; DeBeer, S. Science 2011, 334, 974977.

(15) Wiig, J. A.; Hu, Y.; Lee, C. C.; Ribbe, M. W. Science 2012, 337, $1672-1675$.
(16) Spatzal, T.; Perez, K. A.; Einsle, O.; Howard, J. B.; Rees, D. C. Science 2014, 345, 1620-1623.

(17) Spatzal, T.; Perez, K. A.; Howard, J. B.; Rees, D. C. eLife 2015, 4, e11620.

(18) Spatzal, T.; Schlesier, J.; Burger, E.-M.; Sippel, D.; Zhang, L.; Andrade, S. L. A.; Rees, D. C.; Einsle, O. Nat. Commun. 2016, 7, 10902.

(19) Pham, D. N.; Burgess, B. K. Biochemistry 1993, 32, 1372513731

(20) Howard, J. B.; Kechris, K. J.; Rees, D. C.; Glazer, A. N. PLoS One 2013, 8, e72751.

(21) Ellis, K. J.; Morrison, J. F. Methods Enzymol. 1982, 87, 405-426.

(22) Hayward, S. Protein Sci. 2001, 10, 2219-2227.

(23) Fay, A. W.; Hu, Y.; Schmid, B.; Ribbe, M. W. J. Inorg. Biochem. 2007, 101, 1630-1641.

(24) Smith, B. E.; Durrant, M. C.; Fairhurst, S. A.; Gormal, C. A.; Grönberg, K. L. C.; Henderson, R. A.; Ibrahim, S. K.; Le Gall, T.; Pickett, C. J. Coord. Chem. Rev. 1999, 185-186, 669-687.

(25) Hu, Y.; Ribbe, M. W. Biochim. Biophys. Acta, Bioenerg. 2013, $1827,1112-1122$.

(26) Dance, I. Sci. Rep. 2013, 3, 3237.

(27) Barney, B. M.; Yurth, M. G.; Dos Santos, P. C.; Dean, D. R.; Seefeldt, L. C. JBIC, J. Biol. Inorg. Chem. 2009, 14, 1015-1022.

(28) Morrison, C. N.; Hoy, J. A.; Zhang, L.; Einsle, O.; Rees, D. C. Biochemistry 2015, 54, 2052-2060.

(29) Yang, K.-Y.; Haynes, C. A.; Spatzal, T.; Rees, D. C.; Howard, J. B. Biochemistry 2014, 53, 333-343.

(30) Bruice, T. C.; Maskiewicz, R.; Job, R. Proc. Natl. Acad. Sci. U. S. A. 1975, 72, 231-234.

(31) Bates, K.; Garrett, B.; Henderson, R. A. Inorg. Chem. 2007, 46, $11145-11155$.

(32) Chen, K.; Hirst, J.; Camba, R.; Bonagura, C. A.; Stout, C. D.; Burgess, B. K.; Armstrong, F. A. Nature 2000, 405, 814-817.

(33) George, G. N.; Prince, R. C.; Bare, R. E. Inorg. Chem. 1996, 35, 434-438.

(34) Einsle, O.; Tezcan, F. A.; Andrade, S. L. A.; Schmid, B.; Yoshida, M.; Howard, J. B.; Rees, D. C. Science 2002, 297, 1696-1700.

(35) Zhang, L.-M.; Morrison, C. N.; Kaiser, J. T.; Rees, D. C. Acta Crystallogr., Sect. D: Biol. Crystallogr. 2015, 71, 274-282.

(36) Good, N. E.; Winget, G. D.; Winter, W.; Connolly, T. N.; Izawa, S.; Singh, R. M. Biochemistry 1966, 5, 467-477.

(37) Kabsch, W. Acta Crystallogr., Sect. D: Biol. Crystallogr. 2010, 66, $125-132$.

(38) CCP4. Acta Crystallogr., Sect. D: Biol. Crystallogr. 1994, 50, 760763

(39) Brunger, A. T.; Adams, P. D.; Clore, G. M.; DeLano, W. L.; Gros, P.; Grosse-Kunstleve, R. W.; Jiang, J.-S.; Kuszewski, J.; Nilges, M.; Pannu, N. S.; Read, R. J.; Rice, L. M.; Simonson, T.; Warren, G. L. Acta Crystallogr., Sect. D: Biol. Crystallogr. 1998, 54, 905-921.

(40) Murshudov, G. N.; Skubak, P.; Lebedev, A. A.; Pannu, N. S.; Steiner, R. A.; Nicholls, R. A.; Winn, M. D.; Long, F.; Vagin, A. A. Acta Crystallogr., Sect. D: Biol. Crystallogr. 2011, 67, 355-367.

(41) Murshudov, G. N.; Vagin, A. A.; Dodson, E. J. Acta Crystallogr., Sect. D: Biol. Crystallogr. 1997, 53, 240-255.

(42) The PyMOL Molecular Graphics System, Version 1.8; Schrödinger, LLC: Cambridge, MA, 2015.

(43) Stoll, S.; Schweiger, A. J. Magn. Reson. 2006, 178, 42-55.

(44) Morgan, T. V.; Mortenson, L. E.; McDonald, J. W.; Watt, G. D. J. Inorg. Biochem. 1988, 33, 111-120.

(45) Spatzal, T.; Einsle, O.; Andrade, S. L. Angew. Chem., Int. Ed. 2013, 52, 10116-10119.

(46) Lukoyanov, D.; Yang, Z.-Y.; Khadka, N.; Dean, D. R.; Seefeldt, L. C.; Hoffman, B. M. J. Am. Chem. Soc. 2015, 137, 3610-3615.

(47) Smith, B. E.; Lowe, D. J.; Bray, R. C. Biochem. J. 1973, 135, 331-341. 